\title{
The Preservation of Groundwater Quality through Aerobic Treatment of Wastewater
}

\author{
N. Nedjah, O. Hamdaoui, and N. Laskri
}

\begin{abstract}
Adrar, a city located at the extreme western south of Algeria, uses underground water as the unique source of drinking water, unfortunately, this ground water is subject to contamination by the ceaseless urban water discharged by the city.The objective of this work is to examine the efficency of the biological treatment of this raw waste water through natural lagoon; prior to their release into the receiving environmlent ; by the removal of elements characteristics of pollution mainly DCO, MES, $P$ and $N$, we have found a removal efficiency in DCO of $63 \%$, in MES $66 \%$, nitrites and nitrates70\% and $40 \%$ of phosphorus. These findings are considered satisfactory and hence prevent the contamination of drinking water and preserve the quality of Adrar's ground water.
\end{abstract}

Index Terms-Ground water, wastewater, lagoons, environment.

\section{INTRODUCTION}

Our country as many others is faced with the challenging issues of population growth and land settlement to harmoniously combine economy and ecology, that is to say, meet the needs of goods production and services without modifyin or destroying the quality of water, soil, and air [1], [2].

This work attempts to apply a biological treatment in order to remove organic pollutants from wastewater discharges while safeguarding the quality of our groundwater.

\section{A. Presentation of Adrar: Study Area}

Adrar is the first of the 48 Algerian cities according to the Algerian administrative division in 1995. It is a saharian town in the southern wester of Algeria, bordered on the north by the wilaya of El Bayedh and Ghardaia the west by Bechar and Tindouf, the east by Tamanrasset and south by Mauritania and Mali. The wilaya of Adrar covers a total area of 427,698 $\mathrm{km}^{2}$ in 2008 for a global population, estimated in 2008, of more than 389.898 inhabitants. The region is formed by four major geographical areas from north to south as it is shown in the Fig. 1 and consists of 11 Daïras, 28 towns and 299 Ksars (villages). It is characterizd by a continental desert climate with rare /even insignificant rainfall, the annual average for the period 2000-2010 is $12 \mathrm{~mm}$.

- The GOURARA: Timimoun Region,

- The TOUAT: Adrar region,

- The TIDIKALT: Aoulef région,

Manuscript received April 27, 2014; revised July 1, 2014.

N. Nedjah is with the Preparatory School Science and Technology (EPST Annaba), Algeria (e-mail: nedjah23nawel@gmail.com).

O. Hamdaoui is with the University Badji Mokhtar, Faculty of Engineering Sciences, Laboratory of Environmental Engineering Annaba, Algeria (e-mail: ohamdaoui@yahoo.fr).

N. Laskri is with the Preparatory School Science and Technology (EPST Annaba), Algeria (e-mail: laskri_n@yahoo.fr).
- The TANEZROUFT: Bordj Baji Mokhtar region

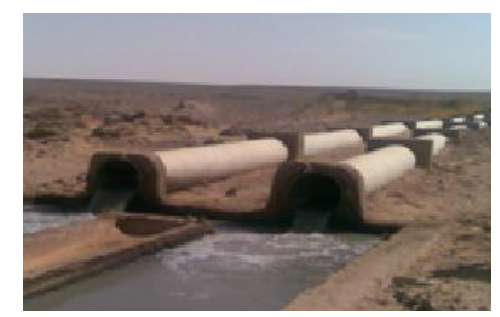

Fig. 1. Input of wastewater treatment plant。

\section{1) Agricultural activity}

Adrar is a city with an agricultural vocation characterized by palm oasis and traditional irrigation system "Fouggara". It is known for its production of dates and tomatoes. The distribution of agricultural land in the municipality of Adrar is presented as follows in the Table I:

TABLE I: Distribution OF AgRICULTURAL LAND IN THE MUNICIPALITY

\begin{tabular}{ll}
\multicolumn{2}{c}{ OF ADRAR } \\
\hline \hline total agricultural area & $43358,5(\mathrm{HA})$ \\
$\begin{array}{l}\text { Usable agricultural area } \\
\text { Number of agricultural holdings }\end{array}$ & 890 \\
$\begin{array}{l}\text { Usable agricultural irrigated } \\
\text { area }\end{array}$ & $1653(\mathrm{HA})$ \\
\hline \hline
\end{tabular}

\section{METHODOLOGY}

\section{A. Wastewater System}

Before the creation of the sewerage system in the city, the inhabitants used a traditional drainage systen similar to a septic tank that causes several health problems. Nowadays, about $98 \%$ of the sewerage system in the city of Adrar is bound. It forms a joint network of $178.91 \mathrm{~km}$ length, with diameters ranging from $\varnothing 200$ and $\varnothing 600$ of PVC type or cement. The daily wastewater volume is set at $80 \%$ of the volume of the consumed drinking water.

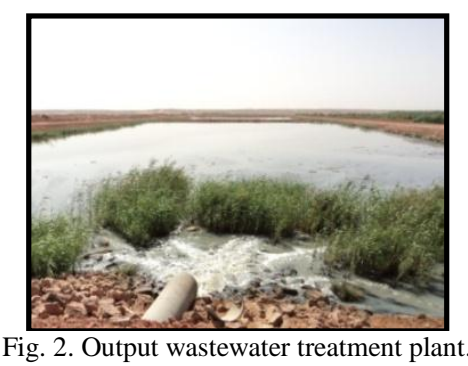

\section{B. Lagoon Koussen}

The principle of wastewater by natural or ecological lagoon has been known since antiquity. Indeed, the 
self-purification processes involved in this technique generates a chain of purifying reactions, occurs spontaneously in which micro- organics degrade the organic matter and convert it into minerals harmless to the receiving environment [3], [4] Under these conditions, it is deemed possible to obtain an excellent organic remediation, and a excellent microbial decontamination [5], [6]. The Settling ponds of Adrar consist of three (03) sets of three (03) ponds for each as it is shown in the following figures: Fig. 1, Fig. 2 and Fig. 3.

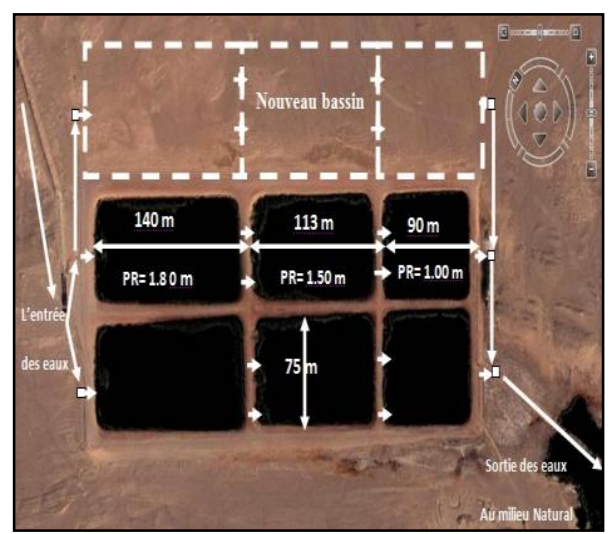

Fig. 3. Size of wastwater treatment plant of ponds

Water quality of Ksar TIDMAINE (region of TOUAT):

Demands for fresh water are increasing every year from $4 \%$ to $5 \%$ while the natural resources remain invariable if not decreasing, due to pollution because of the infiltration of waste water. We have determined the physico-chemical composition of the water of TIDMAINE, the sample taken from the water of this region presents the physico-chemical analysis shown in Tables II, III and IV.

The different physico-chemical parameters, as it shown in Table II, of the water of Tidmaine's region employ three main methods to mention [7]:

- Volumetric method,

- Titrimetric method

- Comolrimetric method.

\begin{tabular}{ll} 
TABLE II: PHESICO-CHEMICAL PARAMETERS \\
\hline \hline Global mineralization. & Result \\
$\mathrm{CA}[+++] \mathrm{MG} / \mathrm{L}$ & 123 \\
$\mathrm{MG}[++] \mathrm{MG} / \mathrm{L}$ & 77 \\
$\mathrm{NA}[+] \mathrm{MG} / \mathrm{L}$ & 229 \\
$\mathrm{~K}[+] \mathrm{MG} / \mathrm{L}$ & 14 \\
$\mathrm{CL}[-] \mathrm{MG} / \mathrm{L}$ & 350 \\
SO4[--] MG/L & 395 \\
$\mathrm{HCO}[-] \mathrm{MG} / \mathrm{L}$ & 171 \\
$\mathrm{CO} 3[--] \mathrm{MG} / \mathrm{L}$ & 0 \\
$\mathrm{SIO} 2 \mathrm{MG} / \mathrm{L}$ & 10.60 \\
$\mathrm{TH} \quad{ }^{\circ} \mathrm{F}$ & 62 \\
$\mathrm{TAC} \quad{ }^{\circ} \mathrm{F}$ & 14 \\
TA ${ }^{\circ} \mathrm{F}$ & 0 \\
$\mathrm{MINÉRALIZATION} \mathrm{MG/L}$ & 1383 \\
AMONT OF IONS MG/L & 1422 \\
MN MG/L & - \\
\hline \hline
\end{tabular}

According to the values in the Table III, it is clear that the $\mathrm{pH}$ and conductivity are in the standards so that water is not subject to contamination by microorganisms, then it is of good quality and safe. The same applies to the turbidity of this water before settling is very low and after settling, it is zero, so the water is not charged for suspension [8].

\begin{tabular}{ll}
\multicolumn{2}{c}{ TABLE III: FACTORS OF POLLUTION } \\
\hline phesico-chemical parameters & result \\
PH & 7.14 \\
CONDUCTIVITY ( MS/CM) & 2.23 \\
TURBIDITY (NTU) & 0.22 \\
TURBIDITY OF DECANTED & 0.00 \\
WATER( NTU) & 1400.00 \\
DRY RESIDU A $110^{\circ} \mathrm{C} \mathrm{MG/L}$ & $15.5^{\circ} \mathrm{C}$ \\
TEMPERATURE ${ }^{\circ} \mathrm{C}$ & \\
\hline
\end{tabular}

But, the values of nitrates are high by the standards, and even the oxydizable material, its value is moderately higher standards as it shown in Table IV, these results assume that the water could be contaminated?

\begin{tabular}{ll}
\multicolumn{2}{c}{ TABLE IV: MiNERALIZATION RATES } \\
\hline \hline Pollution Parameters. & Results \\
DISSOLVED OXYGEN ( MG/L) & - \\
NH4[+] MG/L & ID \\
NO2[-] MG/L & ID \\
NO3[-] MG/L & 62.00 \\
PO4[-] & ID \\
MATTER .OX ( MG/L) & 5.10 \\
IRRON (MG/L) & - \\
\hline \hline
\end{tabular}

And to see better the quality of our water, with the physico-chemical parameters shown in Tables III and IV, we define the standards values of all the parameters that characterize the quality of drinking water. The following Table $\mathrm{V}$ shows the standards parameters of drinking water [9].

TABLE V: STANDARDS OF DRINKING WATER

\begin{tabular}{|c|c|c|c|}
\hline $\begin{array}{l}\text { Standard } \\
\text { Parameters }\end{array}$ & OMS & French & Algeria \\
\hline pH & $6,5-9$ & $6,5-8,5$ & $6,5-8,5$ \\
\hline Conductivity $\left(\mu \mathrm{s} / \mathrm{cm}\right.$ a $\left.20^{\circ} \mathrm{C}\right)$ & - & 400 & 2800 \\
\hline Oxydizability (mg d'O2 /) & 5 & 5 & 3 to the $\max$ \\
\hline Total hardness $\left({ }^{\circ} \mathbf{F}\right)$ & 50 & 60 & 10 to 30 \\
\hline $\mathrm{Ca}++(\mathrm{mg} / \mathrm{l})$ & - & 100 & $75-200$ \\
\hline $\mathrm{Mg}++(\mathrm{mg} / \mathrm{l})$ & - & 50 & 150 \\
\hline Alkalinity $\left({ }^{\circ} \mathbf{F}\right)$ & 50 & $>2,5$ & 50 \\
\hline $\mathrm{Cl}^{-}(\mathrm{mg} / \mathrm{l})$ & 250 & 250 & $200-500$ \\
\hline $\mathrm{SO}_{4}^{2-}(\mathrm{mg} / \mathrm{l})$ & 400 & 250 & 250 \\
\hline Turbidity (NTU) & - & - & - \\
\hline $\mathrm{NO}_{2}^{-}(\mathrm{mg} / \mathrm{l})$ & 40 & 50 & 50 \\
\hline $\mathrm{NO}_{3}^{-}(\mathrm{mg} / \mathrm{l})$ & 3 & 0,1 & 0,1 \\
\hline $\mathbf{K}+(\mathbf{m g} / \mathbf{l})$ & - & 150 & 200 \\
\hline $\mathrm{NH}_{4}^{+}(\mathrm{mg} / \mathrm{l})$ & 1,5 & 0,5 & 0,5 to the max \\
\hline Dry residu at $180^{\circ} \mathrm{C}(\mathrm{mg} / \mathrm{l})$ & - & - & $1500-2000$ \\
\hline
\end{tabular}

By comparing the findings of each physicochemical parameter with those of the international standards, on average the water is of drinkable quality except for the high content of nitrates which suspect pollution due to waste water infiltration [10].

So the need and the urgency to treat waste water before being discharged into the receiving environment, Adrar choses to purify the natural waste water rejection by lagoon, 
and hence, preserves the drinkable water quality coming from the underground layers [11].

\section{INTERPRETATION OF RESULTS}

The physico-chemical analyses are conducted on several samples taken during the month of May 2011, the sampling was done in two different points, the first is the upstream part of the basin and the second is the downstream parts. The following Table VI summarizes the physico-chemical characteristics of a representative sample (wastewater) before and after the biological treatment.

\begin{tabular}{lll} 
TABLE VI: PHYSICO-CHEMICAL CHARACTERIZATION OF THE WASTE \\
BEFORE AND AFTER TREATMENT WITH NATURAL LAGOON WATER \\
\hline & $\begin{array}{l}\text { upstream of } \\
\text { the basin }\end{array}$ & $\begin{array}{l}\text { Downstream } \\
\text { of the basin }\end{array}$ \\
$\mathrm{PH}$ & 8.10 & 8.03 \\
$\mathrm{~T}^{\circ}$ & 27.80 & 27 \\
$\mathrm{G}(\mathrm{MS} / \mathrm{CM})$ & 1.82 & 0.74 \\
$\mathrm{NH}_{4}{ }^{+}(\mathrm{MG} / \mathrm{L})$ & 2.20 & 1.30 \\
$\mathrm{NO}_{2}{ }^{-}(\mathrm{MG} / \mathrm{L})$ & 0.19 & 0.04 \\
$\mathrm{NO}_{3}{ }^{-}(\mathrm{MG} / \mathrm{L})$ & 7 & 2 \\
$\mathrm{PO}_{4}{ }^{3-}(\mathrm{MG} / \mathrm{L})$ & 14.80 & 8.60 \\
$\mathrm{DCO}(\mathrm{MG} / \mathrm{L})$ & 249 & 90 \\
$\mathrm{TUB}(\mathrm{MG} / \mathrm{L})$ & 60 & 20 \\
\hline \hline
\end{tabular}

The raw wastewater of $27^{\circ} \mathrm{C}$ of temperature is rich in organic matter and alkaline nature of $\mathrm{pH} 8$. In addition, this wastewater has high concentration in nitrate and phosphate.

At the end of the treatment and at the exit of the treatment plant, purified wastewater becomes poor in organic matter, phosphates, nitrates and suspended solids; this aerobic treatment enabled the elimination of this harmful pollution and the preservation of the groundwater and the environment as well.

For a more understanding of the effectiveness of this biological treatment, we calculated the removal efficiency of each pollution characteristic as it is demonstrated in the following Table VII.

\begin{tabular}{cl} 
TABLE VII: EFFICIENCY OF THE BIOLOGICAL TREATMENT \\
\hline \hline Paramètres de pollution & Efficiency $(\%)$ \\
DCO (MG/L) & 63.85 \\
TUR (MG/L) & 66.67 \\
$\mathrm{NO}_{2}^{-}{ }^{-}(\mathrm{MG} / \mathrm{L})$ & 78.94 \\
$\mathrm{NO}_{3}^{-}(\mathrm{MG} / \mathrm{L})$ & 71.43 \\
$\mathrm{PO}_{4}{ }^{3-}(\mathrm{MG} / \mathrm{L})$ & 41.89 \\
\hline
\end{tabular}

We notice from the Table VII, that the removal efficiency of pollution parameters is good. This aerobic biological treatment allowed maximum removal of the organic matter, turbidity present and existing forms of nitrogen in the waste water, however the removal efficiency of phosphate is average.

Nitrogen and phosphorus are essential growth elements for microorganisms used in wastewater treatment; therefore, during all biological treatment, some level of nutrient removal occurs[12].
Aerobic biological treatment is effective for this type of climate as well as the nature of physico-chemical [13] of the raw wastewater indicated in Table III and IV above.

\section{CONCLUSION}

The population growth led to an increase in water consumption, therefore, an increase in the volume of waste water discharged into receiving environments. The Coverage for drinking water and sanitation becomes a goal hard to achieve in our country. To this end the waste water presents a serious threat to public health, ecosystems, and even the economy. Faced with growing water needs, our country is bound to preserve the quality of drinking water especially groundwater and developing various methods to get it from sea water and wastewater under technically, economically and environmentally permissible conditions.

Water consists the essence of our life; however, it can be a source of disease. As far as Adrar city is concerned, groundwater is the only source of drinking water and even if the water is deep underground, it may be contaminated by the infiltration of domestic waste water discharged by the city. For the prevention of ground water contamination, the city of Adrar resolved this issue by treating the discharge of urban waste water through biological treatment and more specifically by natural lagoon. This treatment resulted in almost complete degradation of pollutants.

\section{REFERENCES}

[1] S. E. Manahan, "Environmental science, technology, and chemistry," Environmental Chemistry, Boca Raton: CRC Press LLC, 2000.

[2] Reynolds, The Lakes Handbook: Lake Restoration and Rehabilitation, Black Well Publishing, 2005, ch. 2.

[3] F. Edline, Operation of Municipal Wastewater Treatment Plants, Management and Support Systems, Manual of practice, sixth Edition, WEF Press, 2008, vol. 1, no. 11.

[4] A. Stoddard et al., Municipal Wastewater treatment: Evaluation Improvement in National Water Quality, John Wiley \& sons Inc, 2003.

[5] H. Roques, Fondement Théoriques Du Traitement Des Eaux, Tec \& doc Lavoisier éd, Paris, 1990.

[6] M. D. Duncan, Domestic Wastewater Treatment in Developing Countries, Earthscan, UK, 2004.

[7] N. Milaude, "le traitement des eaux usées des communes à forte population estivale," Eau L', L'Industrie, Les Nuisances, no. 113, pp. $55-57,1990$.

[8] N. P. Cheremisinoff, Handbook of Water and Wastewater Treatment Technologies, Butterworth-Heinemann, 2002.

[9] G. Martin, L'Epuration Et Le Traitement Des Effluents (Eau Et Air), Ed TEC \& DOC, 1985.

[10] J. Rodier, Analyse De L'Eau, 7th édition, Dunod, 1984.

[11] T. Asano et al., Water Reuse: Issues, Technologies and Applications, Metcalf \& Edy Inc, 2007.

[12] M. Larpent-Gougnard and J. J. Sanglier, Biotechnologie: Principes et Méthodes, Doin, 1992.

[13] N. Kibi, J. L. Sasseville, J. M. Martel, and J. F. Blais, "Choix multicritère de procédés d'épuration des eaux usées municipales," Revue Des Sciences De L'Eau, Journal of Water Science, vol. 13, no. 1, pp. 21-38, 2000.

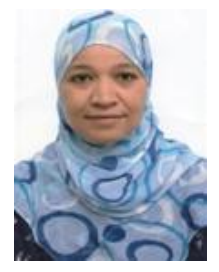

Nawel Nedjah was born on December 29, 1970 in Annaba, Algeria, she holds a magister degree in chemical engineering in 2002 at the Department of Process Engineering and currently she is conducting her PhD studies. From 2003 to 2006 she worked as a researcher in renewable energy center, and then she moved to the university as a lecturer until to 2012 . Now she occupies the position of a professor at the Preparatory School of Sciences and Technology, Annaba, Algeria. 
Nabila Laskri was born on November 20, 1969. in Annaba, Algeria. She holds a magister degree in chemical engineering in 2000 at the Department of Process Engineering and currently she is conducting my PhD studies. From 2003 to 2005. She worked as a researcher in renewable energy center, and then she moved to the university as a lecturer until to 2012 Now she occupies the position of a professor at the Preparatory School of Sciences and Technology, Annaba, Algeria.

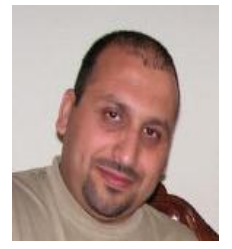

Oualid Hamdaoui graduated with his engineering degree at the Department of Process Engineering, University of Annaba and received his magister and $\mathrm{PhD}$ at the same department in 1997 and 2004 respectively. He is working as a senior lecturer at the process engineering department since 2005. He is member of the Laboratory "Molecular Chemistry and Environment", University Savoie, France, as well as a conference session chair and technical review committee. 